\title{
AGENCY LAW AND CONTRACT FORMATION
}

May 26, 2003

Eric Rasmusen ${ }^{1}$

Indiana University Foundation Professor, Dept. of Business Economics and Public Policy, Kelley School of Business, Indiana University. Erasmuse@indiana.edu. Http://Php.Indiana.edu/ erasmuse/papers/agency.pdf. (812) 855-9219. Fax: (812) 8553354.

${ }^{1}$ I thank Stephen Bainbridge, Royce Barondes, Jeanne Carlson, Edwin Greenebaum, William Klein, Sean Mead, Larry Ribstein, Kathryn Spier, participants in seminars at the Midwest Law and Economics Association Meeting, Indiana University's Kelley School of Business and Cardozo, Georgetown, Northwestern, and Quinnipiac Law Schools, and especially Deborah DeMott and J. Mark Ramseyer for helpful comments.

Send correspondence to: Eric Rasmusen, Indiana University Foundation Professor, Department of Business Economics and Public Policy, Kelley School of Business, Indiana University. Erasmuse@indiana.edu. Http://Php.Indiana.edu/ erasmuse/agency.pdf. (812) 855-9219. Fax: (812) 855-3354. 
A number of issues in the common law arise when agents make contracts on behalf of principals. Should a principal be bound when his agent makes a contract on his behalf that he would immediately wish to disavow? The tradeoffs resemble those in tort, so the least-cost avoider principle is useful for deciding when contracts are valid, and may be the underlying logic behind a number of different doctrines in agency law. In particular, an efficiency explanation can be found for the undisclosed principal rule, under which the principal is bound even when the third party with whom the contract is made is unaware that the agent is acting as an agent. 


\section{Introduction}

The importance of agency in the common law is shown by its being the subject in 1933 of the second (after Contracts) of the American Law Institute's series of Restatements. No business owner can do everything himself. He must delegate some things to agents, and this is true not only for large corporations, but for any business with employees. This is particularly true, of course, once the organization has more than one owner. In partnerships, the partners act as each other's agents. And in corporations, the shareholders are completely unable to act on their own behalf; they delegate authority to a board of directors, which in turn delegates authority to officers. Indeed, agency is one of the main themes of corporate law, and a standard introductory section of its textbooks

The first Restatement was followed by a second, and now the third has reached draft stage (American Law Institute, 2000; see also DeMott, 1998, an article by the Restatement's current Reporter). Since the 1970's agency has also been at the center of some of the most exciting research in economics. Economists have used the idea of principal and agent to explain the intricacies of labor compensation, the organization of hierarchies, the design of securities, and a host of other problems (see, e.g., the books by Milgrom and Roberts, 1994; Spulber, 1999; and Rasmusen, 2001a). In the paradigmatic model, a principal hires an agent to exert some kind of effort. The agent is tempted to be slack in his effort and the principal tries to overcome this moral hazard by designing a contract under which agent compensation is based on output. The economist's issues are, to be sure, different from that of traditional agency law. The economist's concern is that the contract will not induce appropriate effort by the agent; the lawyer's concern is what happens when the agent is active, but his effort is mischanneled.

The lawyer's agent places an order with a supplier when he has been forbidden to do so; drives the principal's delivery truck into a schoolbus; hires the wrong employee for the principal's business, or sexually harasses a fellow worker. For the economist, the agency problem is how to give the agent incentives for the right action; for the lawyer, it is how to mop up the damage when the agent has taken the wrong action. The paradigmatic problem involves not just principal and agent, but a third party. ${ }^{2}$ The agent's misbehavior may not have any direct adverse effect on the principal. The principal is not in the schoolbus that is wrecked by the agent, and unless the law enforces the contract, he is unhurt by the agent's foolish or unauthorized purchases. Third parties are harmed, however, so government intervention can aid efficiency. When the agent takes a mistaken action, the damage must be allocated to someone---principal, agent, or third party.

This kind of problem is intrinsically amenable to economic analysis. Indeed, Judge Posner uses such analysis in his opinion dissenting from the Seventh Circuit in the two leading sexual harassment cases, Jansen v. Packaging Co. and Ellerth v. Burlington

\footnotetext{
2 A prominent area of agency law which does not involve third parties is the law of fiduciaries: whether the agent has acted properly on behalf of the principal, and how much the agent must compensate the principal for mistakes. See Cooter and Freedman (1991).
} 
(1997), believing it to be more useful than application of the second Restatement of Agency, "that antiquated screed" (at 510).. ${ }^{3}$ I have more faith than Judge Posner in antiquated screeds, however, and hope to show that many of the principles to be found in the common law of agency do have sound foundations--- not in the legal formalisms which courts try to use, but in economic analysis. The economic approach has already been applied to one of the best-known problem of agency law: what happens when an agent tortiously injures a third party. The law deals with these involuntary creditors according to the doctrines of vicarious liability or respondeat superior, which make the principal liable for torts committed by his agent in the course of the agent's duties. ${ }^{4}$ Here, we will address a different, but equally fundamental problem: what happens when an agent makes mistaken contracts on behalf of his principal with a third party?

\section{The Law of Agency}

The Restatement of Agency (Second) defines agency as "the fiduciary relation which results from the manifestation of consent by one person to another that the other shall act on his behalf and subject to his control, and consent by the other so to act." ${ }^{6}$ In the present article, we shall take for granted that the agent does not assume the risks of the enterprise. The problem of allocating loss from mistaken contracts is much easier when the loss can be put on the agent, but that case is relatively uninteresting because the theory is simple and the practical application is limited. Ordinarily, the loss cannot be put on the agent, either because he is not rich enough or because he is a difficult target for litigation, having fled or protected his assets from legal judgements. Moreover, while questions involving the agent's liability for contracts are interesting, much of their analysis revolves around the contract between principal and agent rather than between

\footnotetext{
${ }^{3}$ For argument that the Supreme Court was wrong to apply agency law, see Phillips (1991). ${ }^{4}$ Economic analyses of vicarious liability include Chu and Yingyi (1992), Kornhauser (1982), and Sykes (1984, 1988), as well as pages 204-209 of Landes and Posner (1987). These do not, however, analyze the problem of mistaken contracts, and much of their emphasis is on why the tort victim should sue the principal rather than the agent. See also Fischel and Sykes (1996), which explores similar issues with respect to whether corporations should be criminally liable. ${ }^{5}$ Contract agency law has received much less attention than contract tort law. Three recent exceptions are Whincop (1997) (arguing that the formalist approach is incoherent and using game theory to suggest ten principles for agency contract law); Cohen (2000) (viewing deterrence of collusion between two of the three parties against the other as the basic principle of agency law); and Davis (1999) (his Section V, suggesting third-party monitoring of agents as a reason why their misrepresentations do not invalidate a contract). Casadesus-Masanell and Spulber (2002) address the problem, but with little attention to specific laws. Note, however, the suggestion of a "cheaper loss provider" in the 4th edition of the business associations casebook of Larry Ribstein and Peter Letsou (2003, Section 8.01, at 298).

${ }^{6}$ American Law Institute (1958) (the Restatement). Although I will rely on the Restatement as my guide to the law in this article, it should be kept in mind that it is not binding on judges, who are supposed to follow the decisions in their particular state. Yet, "The Restatement (Second) of Agency is the appropriate place to find the federal common law definition. Courts adopting a federal common law of agency generally follow the Restatement." (Steinberg v. Mikkelsen 1995, at 1436)
} 
agent and third party, so agency issues are secondary. The interesting cases from the point of view of agency law are those in which the agent has created a conflict between the principal and some third party, who must share the loss either because the efficient contract puts the risk there or because the agent cannot be made to pay.

The common law provides six reasons why the principal may be bound by contracts made by the agent: ${ }^{7}$

1. Actual Express Authority. The principal has entered into an explicit agreement with the agent authorizing him to take a particular action; the board of directors votes to authorize the president of their company to purchase a new office building.

2. Actual Implied Authority. The principal has entered into an explicit agreement to employ the agent, and although he has not specifically authorized the particular action at issue, the agent can reasonably infer that authority for that action has been delegated to him. If the general manager of a department store hires clerks, the store is bound by his contract, even if he was not expressly granted that authority (Restatement, $\S 52,73$ ).

3. Apparent Authority. The principal has no agreement with the agent authorizing the action, but a third party could reasonably infer from the principal's conduct that the agent was authorized. ${ }^{8}$ If the home office tells a customer that the sales manager has authority to sell flour without confirmation, and then withdraws that actual authority without telling the customer, the sales manager still has apparent authority. ${ }^{9}$ Apparent authority depends on the beliefs of the third party, not on the actual relation between principal and agent.

4. Estoppel. The principal is "estopped" from objecting to the agreement made by the agent if the principal could have intervened to prevent the confusion over authority; e.g., if the principal overheard the agreement being made and failed to assert that the agent

\footnotetext{
${ }^{7}$ This discussion is taken from Chapter 1 of Klein and Ramseyer (1994), from Steffen (1977) and the Restatement. I have adopted the categories of Klein and Ramseyer, but added estoppel as a separate category. Not all jurisdictions use quite this catalog; Indiana, for example, seems to recognize just the three categories of actual authority, apparent authority, and authority by estoppel. See Hope Lutheran Church v. Chellew (1984) and Secon Service System v. St. Joseph Bank and Trust (Easterbrook, J., 1988) at 36.

${ }^{8}$ "Apparent authority is the power to affect the legal relations of another person by transactions with third persons, professedly as agent for the other, arising from and in accordance with the other's manifestations to such third persons." (Restatement, §8)

${ }^{9}$ As we shall see in Section 4, the law becomes less clear when the principal's words did not create the apparent authority. If a sales manager claims he has authority to sell flour without confirmation from the home office, and such sales are customary in the flour business, then does he have apparent authority? Yes, says North Alabama Grocery Co. v. J.C. Lysle Milling Co. (1921), as described in Steffen (1977) at 128. See also Restatement, §49. Others, however, might classify this as inherent agency power, reaching the same outcome with a different doctrine.
} 
was unauthorized. ${ }^{10}$ Black's Law Dictionary $\left(6^{\text {th }}\right.$ edition, 1990$)$ gives a general definition: "...party is prevented by his own acts from claiming a right to detriment of other party who was entitled to rely on such conduct and has acted accordingly." As one opinion puts it, when applied to agency the following is needed:

In order to prove agency by estoppel, the following elements must be established: (1) intentional or negligent acts of commission or omission by the alleged principal which created the appearance of authority in an agent; (2) reasonable and good faith reliance on the appearance of authority in the putative agent by the third party; and (3) a detrimental change in position by the third party due to its reliance on the agent's apparent authority. (Minskoff Equities v. American Express, 1995)

5. Ratification. If no other authority exists, but the principal confirms the agent's agreement once he learns about it, such ratification binds the principal; a flour salesman promises without authorization to sell eggs to a customer, and his employer later approves the agreement.

6. Inherent Agency Power. The agency relationship may somehow give the agent the power to harm third parties even if there is no manifestation by the principal that the agent is acting on his behalf. ${ }^{11}$ "Inherent agency power" is a term invented to cover this source of liability, which was well known in the common law, if not by this name. ${ }^{12}$ The term was formally introduced in 1958 in the Second Restatement, §8a of which says, "Inherent agency power is a term used in the restatement of this subject to indicate the power of an agent which is derived not from authority, apparent authority or estoppel, but solely from the agency relation and exists for the protection of persons harmed by or dealing with a servant or other agent."

The best-known illustration of inherent agency power in the law of agency and contracts is the classic teaching case, Watteau v. Fenwick (1892). Since this is perhaps the best-known case in the law of agency, raising as it does real problems for legal formalism, it is worth laying out in detail:

\footnotetext{
${ }^{10}$ But see Black's Law Dictionary at 63, which seems to conflate estoppel with apparent authority: "Agency by estoppel: When the principal, by his negligence in supervising the agent, leads a third party to reasonably believe that the agent has authority to act for the principal."

11 "Representations of the principal to the third party are central for defining apparent authority, but in contrast, inherent authority originates from the customary authority of a person in the particular type of agency relationship and no representations beyond the fact of the existence of the agency need be shown." (Cange v. Stotler, 1987)

${ }^{12}$ See, for example, Hubbard v. Tenbrook (1889): "The answer is not at all doubtful. A man conducting an apparently prosperous and profitable business obtains credit thereby, and his creditors have a right to suppose that his profits go into his assets for their protection in case of a pinch or an unfavorable turn in the business." The Hubbard court tries to justify this statement in terms of apparent authority and estoppel, but neither doctrine quite fits. Not all states accept inherent agency power. McKay (1994) discusses the current status of inherent agency power in state law, with special emphasis on Texas. It is dropped from the draft of the Third Restatement (Tentative Draft No. 1 (March 20, 2000) xvii, 89). See also Fishman (1987), which briefly mentions the objective of encouraging the least-cost avoider to take precautions, at 54, though his article does not take the economic approach.
} 
"From the evidence it appeared that one Humble had carried on business at a beer-house called the Victoria Hotel, at Stockton-on-Tees, which business he had transferred to the defendants, a firm of brewers, some years before the present action. After the transfer of the business, Humble remained as defendants' manager; but the license was always taken out in Humble's name, and his name was painted over the door. Under the terms of the agreement made between Humble and the defendants, the former had no authority to buy any goods for the business except bottled ales and mineral waters; all other goods required were to be supplied by the defendants themselves. The action was brought to recover the price of goods delivered at the Victoria Hotel over some years, for which it was admitted that the plaintiff gave credit to Humble only: they consisted of cigars, bovril, and other articles. The learned judge allowed the claim for the cigars and bovril only, and gave judgement for the plaintiff for $22 \mathrm{~L} .12 \mathrm{~s} .6 \mathrm{~d}$.

There is no actual authority, either express or implicit, for the agent to order the cigars, because he was expressly instructed not to order them. There is no apparent authority, because the principal did nothing to convey the idea that the manager was acting as an agent. The plaintiff might be estopped from denying that Humble was his agent, since Humble was put in a position to so act, but estoppel would only permit recovery of the cost of the goods to the seller, not their price. Ratification does not apply. All that remains is "inherent agency power": the ability of the manager, based on his employment by the principal, to harm third parties by making contracts.

When analyzing a given case between a principal and a third party involving liability for a contract made by an agent, a court can draw upon a number of doctrines, but the variety of doctrines is a sign more of the difficulty the court is in than of the ease with which it can find a definite solution. The doctrines require considerable thought in their application. What makes authority "express"? How apparent does "apparent authority" have to be? When does the judge pull out the last resort of "inherent agency power"? All of these doctrines are applied haphazardly, giving rise to the suspicion that judges are deciding how the cases should come out on common-sense grounds (usually quite reasonably) and then groping for legal formalisms. ${ }^{13}$

\footnotetext{
${ }^{13}$ See Whincop (1997) for a discussion of the confusion of the formalist approach, with illustrations from Australian cases. His list of proposed new doctrines may be seen to come to much the same conclusions as existing law, however, and fits well with the least-cost avoider analysis below. Examples of items are:

"(4) The contractor's ability to enforce a contract should be limited where the transaction is one where the contractor would normally collect information concerning the client before a decision to proceed the transaction was made, but did not in fact do so.

(5) A company should not be able to assert against the contractor a nonstandard allocation or delegation of power."

Two interesting recommendations he makes are:

"(8) Civil remedies should permit courts to divide the loss of unauthorised transactions where the taking of precautions by both parties is desirable.

(9) Where the incidence of unauthorised dealings is very low for the sort of transaction involved in the instant case, the loss should lie where it falls."
} 
I agree with Judge Hand that agency law does reach the right results, even if agency doctrine is not always clear. As in other areas of the law where morality and legal rules leave us in confusion, efficiency may here come to our aid as a unifying principle of considerable appeal. It will be particularly appealing here as a justification and clarification for the doctrines above rather than merely replacing them outright. We will thus explore an efficiency interpretation of the sources of authority in Section 3.

\section{A Model of Contracts Made by Agents}

A formal model may help to clarify the tradeoffs involved in agency law, even though we shall not mathematically manipulate it here. The principal wishes to buy a good he values at $V_{p}$, which costs the third party a lesser sum $V_{t}$ to produce. The principal can either buy the good directly, at transaction $\operatorname{cost} c_{n a}$, or hire an agent, at the lower cost $c_{a}$. With probability $f$, the agent mistakenly orders the wrong good, which the principal values at only $\left(V_{p}-X\right)$ and which cannot be resold for more than that amount. The agent error has a probability given by a convex function $f\left(c_{p}, c_{t}\right)$ which is decreasing in $c_{p}$ and $c_{t}$, the care the principal and the third party take to prevent the error, with diminishing returns to each kind of care.

Our focus will be on the choice of the care levels $c_{p}$ and $c_{t}$. The principal's care, $c_{p}$, has a large number of interpretations. It is he who has made an agreement with the agent, and at some cost he can incorporate incentives to deter agent error. This cost includes the cost of formulating and negotiating the agreement, the cost of compensating the agent for his increased effort to avoid errors, and the cost of incentives under imperfect information (e.g., increased risk-bearing by the agent and the real costs of punishments). The principal can also exert care by choosing agents carefully and by monitoring them to increase the agent's incentives to avoid error and to catch erroneous contracts before any reliance costs are incurred. The care level $c_{p}$ incorporates all these avenues of error avoidance.

The third party has less scope for avoiding agent error because he does not select or compensate the agent. His chief advantage is that he is on the spot when the contract is being formed, so he can detect some errors more easily. Even if he does not know the principal's desire perfectly, the third party can detect gross agent errors, take care to avoid inducing agent error, ask about the agent's instructions, and contact the principal directly for confirmation. These comprise the care level $c_{t}$.

If no agent is used, the principal pays the transaction cost. The price is falling in $\mathrm{c}_{\mathrm{na}}$, so the principal and the third party share any reduction in the transaction cost. The principal receives a direct benefit, paying out a smaller $\mathrm{c}_{\mathrm{na}}$, and the third party receives an indirect benefit, a higher price.

If the agent is used, an error may occur, in which case it is efficient to breach the erroneous contract and write a new contract correcting the error. The individual payoffs

depend on who pays the agent, and on the legal rule. The social surplus regardless of the 
legal rule, consists of the gains from trade, $\left(V_{p^{-}} V_{t}\right)$, the expected loss due to error, $f\left(c_{p}, c_{t}\right)$ $X$, the cost of the agent's effort, $c_{a}$, and the care taken to avoid error, $\left(c_{p}+c_{t}\right)$. All these exist regardless of the legal rule, which will only affect the levels of $c_{p}$ and $c_{t}$, unless it completely chokes off use of the agent.

In the first best, the agent is used if he reduces expected transaction costs. If the probability of agent error falls, the principal receives a direct gain, bearing the mistake cost of $X$ less often, but the third party receives an indirect gain, a higher price. The agent reduces transaction costs, to the benefit of both parties, and both parties should be interested in a legal rule that encourages efficient monitoring. It is not true that when the principal hires the agent it helps the principal alone. A reduction in transaction costs helps both sides of the transaction.

This is itself an important point about agency. The agent helps both sides of the transaction, and an efficient legal rule benefits both buyer and seller. As a result, it is wrong to try to decide whether someone is the buyer's agent or the seller's agent by discovering who is the beneficiary of his actions. Everyone is a beneficiary. A better approach is to ask who has control over the agent, which in fact is the usual legal rule. Both parties, however, have some control over him, as in the model above, where both principal and third party can take care to prevent agent mistakes. The principal has authority, and usually has more control, but his power is limited by his absence from the time and place of the transaction.

Consider a real estate broker selling a house. He is the seller's agent, owing a fiduciary duty to the seller, and the seller pays him the commission. At the same time, he does have duties to buyers, he spends much more time with them than with the seller, and he depends on buyers for success in gaining any commission at all. Moreover, from an economic point of view, the buyer pays the commission just as much as the seller does. Appearances are so deceiving that buyers commonly and wrongly believe that the broker is acting on their behalf, not the seller's, and owes them fiduciary duties. That is false, ${ }^{14}$ but it can easily happen that the broker is much more useful to the buyer than to the seller, his principal. It may happen that absent the broker, the seller could find many equivalent buyers for his house, but that the buyer could not find any house that so well met his needs.

While it is clear that an effective agent helps both principal and third party, the great question in agency law is which should bear responsibility for the agent's mistakes or malfeasance. We can use efficiency as a criterion, asking what legal rule would bring us closest to the optimal levels of care, $c_{p}$ and $c_{t}$ and thereby make both parties better off ex ante. The difficulty is that care by both principal and third party is desirable. Contract law ordinarily either upholds or voids an agreement. If the rule is that mistakes by an agent are immaterial to the validity of a contract, the third party will not take care. If the

\footnotetext{
${ }^{14}$ For example: "(c) A broker engaged by a seller or landlord owes no duties or obligations to the buyer or tenant except that a broker shall treat all prospective buyers or tenants honestly and shall not knowingly give them false information.' (Indiana Code, §25-34.1-10-10, 1996)
} 
rule is that mistakes by the agent void a contract, the principal will not take care. ${ }^{15}$ Nor would it be enough to go beyond standard contract doctrine to something more like tort law's comparative negligence, sharing the cost of agent error between principal and third party. ${ }^{16}$ This would give each some, but not sufficient, incentive to take care.

The problem is a variant of the "moral hazard in teams" problem described by Holmstrom (1982). His work implies that any legal rule sharing damages will be inefficient unless it has one of two features:

(1) The rule destroys value by imposing punishments on both the principal and the third party following agent error.

(2) The rule makes use of the care levels $c_{p}$ and $c_{t}$, in allocating liability, punishing suboptimal care.

In Holmstrom's original context of labor contracts, feature (1) takes the form of docking all the workers' pay if their joint output is so low as to show that at least one worker shirked. Workers will agree to this in advance knowing that in equilibrium nobody will shirk under this threat, and if someone did, the employer would gladly carry out the threat. In the context of an erroneous contract, the court would impose the entire loss on each party. Each would then provide the efficient care level, but they would have a strong disincentive to enforce the agreement in court ex post, even if a court would enforce such a contract clause.

Feature (2) is not ordinarily a feature of contract law, but it is the dominant feature of tort law, which often assigns liability based on negligence. Agency law often seems a hybrid between tort and contract. It has the contract feature of agreement between two parties, but the tort features that the two parties-- principal and third party-do not meet and the harm is unintentional.

\footnotetext{
${ }^{15}$ For a straightforward algebraic analysis of the effect of different legal rules, see the early, more technical version of this paper, Eric Rasmusen, The Economics of Agency Law and Contract Formation, May 8, 1995, http://Php.Indiana.edu/ erasmuse/papers/agency.1995.pdf (March 3, 2001).

${ }^{16}$ Posner (1986) suggests that unlike in tort, in contract it is usually very clear that only one party could have prevented breach. The performer failed to perform, which the payer could not prevent, or the payer failed to pay, which the performer could not prevent. An exception to the indivisibility of liability is the rule of Hadley v. Baxendale, under which the breacher is not liable for unforeseeable damages (Hadley v. Baxendale, 1854). Since he does pay compensation only for the immediate damages from breach, this splits total damages. It allocates each type of damage completely to one party or the other, however, and the unforeseeability of the uncompensated damages from the point of view of the breacher means that it would be inefficient to make him liable for them. A more obscure example is the provision in the Mongolo-Oirat Regulations of 1640 that if a third party buys stray cattle from a finder the loss is split-- the original owner is entitled to the head and the third party to the rump. Similar splits were common in other areas of accident law in Mongolia (Levmore, 1987).
} 
As a result, the Coase Theorem is less helpful than it usually is in contract situations. Ordinarily, discussions of the economics of contract law qualify their conclusions by saying that the welfare loss from an inefficient legal default rule is limited to transaction costs, because the parties can always contract around the inefficient rule. That is more difficult when such contracting-around must be done by the very agent whose errors are the source of the problem. The limitation on losses only applies in the sense that the parties can always dispense with using an agent if agency law is too inefficient. Not using the agent could be the second-best-efficient outcome, if optimal care levels by both principal and third party still result in high agency costs, since if the third party must bear the cost of agent mistakes, he may decide to refuse to deal with agents in dubious circumstances and insist on direct negotiation with the principal.

Shavell (1980) has made a similar point in the tort context: if an activity is inherently risky, an efficient tort rule should discourage the level of the activity to some extent as well as encouraging proper care when the activity is still undertaken. If the agent is to be retained, however, contracting around inefficient default rules is unsatisfactory, because it is the untrustworthy agent himself who is handling the contracting for the principal. ${ }^{17}$

A more important result of the tort features is that agency law is a field where the older, "Posnerian" style of law and economics still has much to teach us, because the least-cost avoider principle of tort applies. The least-cost avoider-principle, broadly stated, asks which party has the lower cost of avoiding harm, and assigns liability to that party. This is not entirely satisfactory, since it reduces the incentive for the other party to take care, and we are unlikely to get both $c_{p}$ and $c_{t}$, exactly right, but the principle has wide application and is simple enough for judge and jury to use. Moreover, not only does it have desirable efficiency properties, encouraging the parties to take some but not excessive precautions ex ante, it also accords with common ideas of fairness, putting the loss on the party who most people think deserves it in cases where everyday intuition does apply. ${ }^{18}$ Section 4 will examine different types of error, and show how the six sources of agent authority can all be seen as applications of the least-cost avoider principle.

\section{Application of the Least-Cost Avoider Principle}

\section{A. The Sources of Authority}

The six sources of agent authority described in Section 2 can all be derived from the least-cost avoider principle, which explains why it is often more difficult to decide which legal doctrine applies in a particular case than to decide where the law places liability.

\section{Actual Express Authority}

\footnotetext{
${ }^{17}$ See the Corrupt Treasurer Case in Section 4.B below for an example; the person to ask about whether a transaction was authorized was himself the source of the problem.

${ }^{18}$ One might go further and say that the efficiency properties of the rule are why it seems fair, but that is a subject for a different article.
} 
When the agent has actual express authority, the principal will usually be the least-cost avoider.

Illustration 1: Principal Mistake. $P$ hires $A$ to buy goods from TP. $A$ orders the goods from $T P$. Soon afterwards, $P$ realizes that he cannot make use of the goods. Must $P$ accept delivery and pay $T P$ ?

In Illustration 1, the agent's role is trivial. He carries out the wishes of the principal to the letter, and when the principal is mistaken ex post, it is not because he employed an agent. It is a useful starting point, however, because both $P$ and $T P$ could conceivably have prevented the harm, yet we place responsibility on $P$. Why not have a rule that says that sellers must take due care that the buyers can really use the goods? This is not, of course, a problem limited to contracts by agents, but it must be cleared up before we continue. ${ }^{19}$

$P$ is the natural least-cost avoider, because he should know better than anyone what goods he wants and how much he is willing to pay for them. Determining even one's own tastes is costly, but trying to determine someone else's is usually more difficult. This is particularly true when an agent is used, because TP does not even meet $P$ face to face and so has little idea of $P$ 's motivation.

Even so simple a point, however, has its exceptions. Although $P$ knows his tastes best, if $T P$ knows the goods he is selling best, it may be $T P$ who can most cheaply avoid mistaken contracts. This is the basis for the formation defenses of fraud and misrepresentation which a defendant may use when accused of breach of contract. It is also the basis for many common business practices such as warranties and explicit or implicit money-back guarantees. Warranties are a good example, however, of how if the legal default is that $P$ is responsible, but $T P$ is the least-cost avoider, the contract can be modified to shift the risk of mistake onto $T P$.

\section{Actual Implied Authority}

In Illustration 1, the considerations involved differ little from when a contract is made without an agent, except for $T P$ 's high cost of discovering the motivation of the party with whom he is ultimately contracting. When actual implied authority is involved, the distinct features of agency come into play, because of the possibility that the agent acts in a way that the principal did not intend and would repudiate immediately upon discovering it. ${ }^{20}$

19 On occasion, the law does recognize that a party to a contract can be protected from his own carelessness. Scriveners' errors are an example: if there is a clear drafting error, such as a missing decimal place, courts will not enforce a contract as written. See Ayres and Rasmusen (1993).

${ }^{20}$ The difference between actual and implied authority is distinct from the difference between a special and a general agent: "(1) A general agent is an agent authorized to conduct a series of transactions involving a continuity of service. (2) A special agent is an agent authorized to 
Illustration 2: Agent Mistake. $P$ hires $A$ as manager for his grocery store. $A$ orders fresh fruit from $T P$, and orders more than $P$ desired. Is $P$ liable on the agreement?

$P$ is liable on the contract because general managers have the implied authority to place orders for fruit. This is a more difficult case than Illustration 1, however. We cannot just say that the buyer is responsible for his promises, because in Illustration $2, A$ is acting contrary to $P$ 's wishes, even if unintentionally. Unlike in Illustration 1 , if $A$ were not employed, the mistaken order would not have occurred, so $A$ is not simply acting in place of $P$. $P$ has, however, intended for $A$ to make contracts of this kind, and knows there is some possibility $A$ will place the wrong order. In this sense, $P$ intended that $A$ place a certain number of wrong orders. This is the same tradeoff between reducing transaction costs and increasing error costs modelled in Section 3. Viewed this way, actual implied authority is close to inherent agency power: the principal has put the agent in a position where the agent can inflict harm on third parties.

The least-cost avoider principle helps clear away some of the confusion over authority. We must ask what general rule of liability would result in the least cost of avoiding this kind of mistake. The principal has a variety of means available to reduce the risk of agent mistakes. He hires the agent, and so can select an agent with the appropriate talents. ${ }^{21}$ He can negotiate a contract to give him incentive to use those talents properly. ${ }^{22} \mathrm{He}$ can instruct the agent to a greater or lesser extent, choosing the level of detail in light of the costs of instruction and mistake. He can expressly instruct the agent not to take certain actions, and tell third parties about the restrictions. ${ }^{23} \mathrm{He}$ can monitor the agent, asking for progress reports or randomly checking negotiations that are in progress. The principal's control over the agent, a basic feature of the agency relationship, gives him many levers with which to reduce the probability of mistakes.

Analogs of some of these levers are available to the third party. He can refuse to deal with with an insufficiently talented agent, though this requires incurring costs to test the agent's talent. Such testing may be no more difficult for the third party than for the principal, but the principal often will be able to spread the fixed cost of testing the agent over many transactions that the agent will make for him. The third party could sign a

conduct a single transaction or a series of transactions not involving continuity of service." Restatement, $\S 3$.

${ }^{21}$ "Where one of two innocent persons must suffer, the loss should be borne by him who put the wrongdoer in a position of trust and confidence and thus enabled him to perpetrate the wrong." (Rykaczewski v. Kerry Home, Inc., 1960, at 465).

${ }^{22}$ See the syllabus in Union Mutual Life Insurance Co. v. Wilkinson (1871): "This principle [that insurance salesmen are agents of the seller, not the buyer] is rendered necessary by the manner in which these agents are sent over the country by such companies, and stimulated by them to exertions in effecting insurance, which often lead to a disregard of the true principles of insurance as well as fair dealing."

${ }^{23}$ If not communicated to the third party, such withdrawal may not affect the manager's power to take such actions, because he may still have apparent authority, but the principal can punish the agent for taking forbidden actions. This (and simply the avoidance of mistakes) is the chief use of hidden instructions, as in Watteau v. Fenwick. 
contract with the agent, specifying that the agent will be punished if the principal disavows the contract, but, again, it may not be worth tailoring a separate incentive contract for each transaction. Or, the third party could monitor the agent by checking with the principal to confirm the transaction. Sometimes this may be efficient, but the trouble to which it puts the principal brings into question the usefulness of hiring an agent in the first place. In light of this, it makes sense to have the principal liable as a general rule when the agent has actual implied authority.

\section{Apparent Authority}

Apparent authority rests on conduct or words of the principal which lead the third party to believe reasonably that the agent is acting with authority. ${ }^{24}$

Illustration 3: The Lingering Agent Problem. P discharges A, his general selling agent, but gives no notice to others. Shortly thereafter, A contracts to sell goods by separate contracts to $X, Y$ and $Z$. $X$ had known of $A$ 's former employment. $A$ showed $Y$ a letter from $P$ to $A$ signed by $P$, stating that $A$ is employed as $P$ 's selling agent. $Z$ had not known of $A$ 's employment and relied wholly on $A$ 's oral statement. ${ }^{25}$ Do $X, Y$, and $Z$ have valid contract claims against $P$ ?

The Restatement says that $X$ and $Y$ have valid claims, but $Z$ does not. This corresponds to the least-cost avoider principle, because for $X$ and $Y$ to check the authority of every well-known or documented agent for every transaction would be more costly than to require $P$ to notify his customers that $A$ has been fired and to demand return of letters of authority. ${ }^{26}$ Furthermore, even if the cost to $P$ of retrieving his letter of authority is high, imposing liability on $P$ discourages him from issuing such a dangerous letter in the first place. Some other sign of authority may be less easily abused. $Z$, on the other hand, has exerted no care to determine that $A$ is $P$ 's agent, and $P$ 's cost of

\footnotetext{
${ }^{24}$ Apparent authority can be either apparent express authority or apparent implied authority, but I have not seen this terminology used anywhere.

${ }^{25}$ Restatement, $\$ 159$. Something very close to Illustration 3 comes up in the Bible: "And he said also unto his disciples, There was a certain rich man, which had a steward; and the same was accused unto him that he had wasted his goods. And he called him, and said unto him, How is it that I hear this of thee? give an account of thy stewardship; for thou mayest be no longer steward. Then the steward said within himself, What shall I do? for my lord taketh away from me the stewardship: I cannot dig; to beg I am ashamed. I am resolved what to do, that, when I am put out of the stewardship, they may receive me into their houses. So he called every one of his lord's debtors unto him, and said unto the first, How much owest thou unto my lord? And he said, An hundred measures of oil. And he said unto him, Take thy bill, and sit down quickly, and write fifty. Then said he to another, And how much owest thou? And he said, An hundred measures of wheat. And he said unto him, Take thy bill, and write fourscore. And the lord commended the unjust steward, because he had done wisely: for the children of this world are in their generation wiser than the children of light." (Luke 16:1-8, King James Version)

${ }^{26}$ This is close to the former dealer rule in partnership law, that when a partnership is dissolved, an erstwhile partner still has the power to obligate the firm until former dealers on credit are notified of the dissolution. See Steffen (1977) at 51 or U.P.A. §35.
} 
advertising to every potential customer that every potential salesman is not his agent is prohibitively high.

The word "reasonably" should tip off the reader that apparent authority is the source of many disputes. Three of them will help illustrate the problems of the third party in discovering that the agent's authority is only apparent.

The Burnt Cotton Case: TP Cannot Discover Actual Authority. In 1863, TP sold 144 bales of cotton to $A, P$ 's agent, for 40 cents a pound. Before the cotton could be put on a boat, 90 bales were burned. P had instructed $A$ to buy at an average price of 30 cents a pound and not vest ownership till delivery at Memphis, so $A$ violated instructions. Must $P$ pay for the burnt cotton? (Butler v. Maples, 1869)

The U.S. Supreme Court agreed that $P$ must pay. $A$ did have express authority to buy cotton for $P$, subject though he was to secret instructions on how to do it. For TP to delay and ask $P$ if $A$ had authority was impractical. Having the express authority to be a general agent, $A$ had the apparent authority to pay the market price for typical terms of delivery. $^{27}$

The Lawyer Madnick Case: TP Cannot Cheaply Discover Actual Authority. Principal Rothman hired agent lawyer Madnick to represent him in a tort suit against third party Fillette. Pennsylvania law requires express authority for a lawyer to settle a case for his client. Madnick settled the Rothman's case without such authority, forged his signature, and cashed the \$7,000 check for himself. Five years later, after Madnick had been disbarred and convicted of forgery unconnected with this case, Rothman sought to reopen his case. Can he-- and does the $\$ 7,000$ count as being paid to Rothman? (Rothman $v$. Fillette, 1983)

A lower court thought that third party Fillette ought to have taken more care to check on Rothman's authority. The appellate court found this absurd and reversed, saying,

"The lower court suggested the following methods for an insurer to ascertain the attorney's authority prior to consummating settlement: (1) compare the signature on the release with the signature in the files; (2) require the release to be notarized; (3) request the claimant to personally execute the release in their presence; and/or, (4) obtain permission to contact the claimant in order to verify settlement.

In our judgment these suggestions are impractical and of little utility for the objectives sought to be achieved. (Rothman v. Fillette, 1983, at 267)

\footnotetext{
${ }^{27}$ Nowadays, UCC $2-509$ would seem to put the loss on the seller in a case like this since the burning occurred before the cotton was put on the carrier. This was not a point mentioned in the Supreme Court's opinion, though, so it would seem the relevant law was different then.
} 
Fillette could have undertaken all four of these checks on Madnick's authority, but at a significant cost, given the unlikelihood of encountering forgery from an attorney. Even in the modern age of telephone and fax, checking up is not cheap. ${ }^{28}$

The Antigua Loan Case: P would Prefer not to be Bothered by TP's Inquiries. Antigua's ambassador to the United Nations borrowed \$250,000 from First Fidelity Bank, purportedly to refurbish the embassy, but actually to invest in a casino. He could not repay, and agreed to a settlement. Was Antigua liable, and was the settlement valid? (First Fidelity Bank, N.A. v. Antigua and Barbuda, 1989).

This case illustrates how high the cost of checking on authority can be. American banks do not have in-house knowledge of Antiguan government procurement procedures. Note, too, that not only the third party, but the principal, directly bears costs from verifying agent authority. The Court held that the ambassador may have had apparent authority, depending on the fact of whether the bank should have known. One judge dissented, objecting to remand on the grounds that apparent authority was obvious enough not to need a determination of fact:

...foreign governments generally will not appreciate inquiries from American vendors as to the authority of their ambassadors to obtain goods or services. ... And how is the vendor to avoid all risk? It cannot obtain a routine resolution of borrowing authority from a corporation's board of directors. Must it inquire of the foreign ministry, the parliament, the head of state? Or should it examine the internal legal regulations that govern the purchasing and borrowing authority of each country's ambassadors? None of these alternatives seems likely to promote this country's relationships with foreign states.

A third party who supplies an embassy (or a UN mission) with champagne or credit expects payment, not an opportunity to persuade a trial court that its ignorance of an ambassador's lack of actual authority was not willful. (First Fidelity Bank, N.A. v. Antigua and Barbuda, 1989, at 199).

Thus, for a variety of reasons, the principal may be the least-cost avoider of agent error even when this requires going beyond issuing careful instructions to the agent with credible threats of punishment for disobeying those instructions. ${ }^{29}$

\footnotetext{
${ }^{28}$ This reasoning is persuasive as far as concluding that third party Fillette ought to be credited with the $\$ 7,000$ he paid agent Madnick. A dissenting appellate judge agreed with this, but thought that Rothman ought to have been allowed to pursue his claim for anything in excess of $\$ 7,000$. Oddly, neither majority nor dissent returns to the seemingly decisive fact that the Pennsylvania statute requires express authority, not just apparent authority, for a settlement. ${ }^{29}$ Curiously, the U.S. federal government has protections under federal common law not available to other principals. In 1995, a federal judge agreed with plaintiff Dupuis that the Federal Home Loan Mortgage Corporation was an undisclosed principal for the bank she dealt with and would liable to her, but "Despite FHLMC's liability at common law (federal or Maine), I conclude that the Merrill doctrine ultimately provides a complete defense to FHLMC on all of Dupuis's contract claims." (Dupuis v. Federal Home Loan Mortgage Corporation, 1995, at 144 )

The Merrill doctrine was created by the U.S. Supreme Court in 1947. Justice Frankfurter wrote that despite "...the theory of the trial judge, that since the knowledge of the agent of a private insurance company, under the circumstances of this case, would be attributed to, and
} 
These cases also illustrate a difficulty in defining apparent authority as a legal concept. I began this section with "Apparent authority rests on conduct or words of the principal...". Illustration 3 did not have this problem. If $P$ tells $T P$ that $A$ has authority, and then $P$ cancels the authority without telling $T P$, then $A$ clearly has apparent authority but not actual authority. If $A$ tells $T P$ that $A$ has authority to act for $P$, when $A$ in fact has never met $P$, then $A$ does not have apparent authority. A maxim of agency law is that an agent cannot create his own authority. But what if $P$ 's conduct has led $T P$ to believe that $A$ has authority? The lines between apparent authority, agency by estoppel, and inherent agency power then become hazy. In the Burnt Cotton Case, the Lawyer Madnick Case, and the Antigua Loan Case, the agent is chiefly to blame for the false appearance of authority, but the principal put him in a position to create that false appearance. The least-cost avoider principle applies relatively simply, but deciding which formalist legal category applies is more difficult.

\section{Agency by Estoppel}

Estoppel is based on the ease with which someone could have prevented harm to himself. Having failed to prevent the harm, he is "estopped" from asserting what would otherwise be a valid claim.

Illustration 4: Estoppel. "P learns that $A$, who has no authority or apparent authority to sell $P$ 's goods, is negotiating with $T P$ as $P$ 's agent for their sale. He does nothing although he could easily notify $T P$. TP pays $A$ for the goods, as is customary in such a transaction. ${ }^{30}$ Must $P$ deliver the goods?

On pure agency grounds, $P$ would be free to refuse to deliver the goods, because $A$ is not his agent and $P$ 's manifestations did not deceive $T P$. Instead, the law requires

thereby bind, a private insurance company, the Corporation is equally bound," the Court would hold that, "Whatever the form in which the Government functions, anyone entering into an arrangement with the Government takes the risk of having accurately ascertained that he who purports to act for the Government stays within the bounds of his authority." (Federal Crop Ins. Corp. v. Merrill, 1947, at 383). The liability of the sovereign is based on its waiver of sovereign immunity, which courts construe narrowly; in an opinion ruling that the Commissioner of the Internal Revenue Service's agreement to a tax settlement was invalid despite his apparent authority because by statute he lacked actual authority without the explicit concurrence of the Secretary of the Treasury, the Court said, "When a statute limits a thing to be done in a particular mode, it includes the negative of any other mode." (Botany Worsted Mills v. U.S., 1928, at 289)

Note that in his Merrill dissent, Justice Jackson uses the least-cost avoider idea: "To my mind, it is an absurdity to hold that every farmer who insures his crops knows what the Federal Register contains or even knows that there is such a publication. If he were to peruse this voluminous and dull publication as it is issued from time to time in order to make sure whether anything has been promulgated that affects his rights, he would never need crop insurance, for he would never get time to plant any crops." (Merrill, at 387)

${ }^{30}$ Restatement, $\S 8 \mathrm{~B}$. See also $\S 31$, Estoppel to Deny Authorization. 
him to deliver the goods on grounds of estoppel: he could have prevented the misunderstanding by repudiating A's statement, but he did not.

This is clearly justified by the least-cost avoider principle. Even though $P$ did not hire $A$, he is the least-cost avoider because he can prevent the mistake more cheaply than $T P$ can. He is therefore liable for the resulting harm (Restatement, $\S 8 \mathrm{~B}$. See also $\S 31$, Estoppel to Deny Authorization).

The common law generally does not impose liability for nonfeasance, only for malfeasance, as in the lack of a duty to rescue. That principle does not apply to agency, as the Restatement explains in a special section on "Estoppel by silence": "The laissezfaire common law rule which imposes no duty to aid others has probably been retained in its extreme form because of the difficulty in fixing limits and in the agency situation, not only is the purported principal in the best position to prevent the harm, but also it is usually not difficult to ascertain what it was reasonable for him to do." ${ }^{31}$ In Metropolitan Club v. Hopper (1927), for example, the secretary of a club ordered, without authority from the club, supplies for a restaurant company operating in the club building. The club would not have been liable, except that it regularly received and ignored copies of the bills. Consequently, it was estopped from denying that the secretary was acting as its authorized agent.

Estoppel has two special features in contrast to other sources of liability (Steffen, 1977, at 128). First, the third party's recovery is limited to the losses caused by the principal's failure to prevent the mistake, rather than including expectation damages. Strictly speaking, the principal's failure does not make an invalid agreement into a contract; it just makes the principal liable for damages. If there is no reliance by the third party, no recovery is possible. Second, estoppel is a one-way street. The third party can obtain damages from the principal, but the principal cannot enforce the agreement against the third party (unless it is made valid by ratification, as discussed below). Estoppel is a concept from the common law of tort and evidence, not contract. These features make it even clearer that the driving idea is the least-cost avoider principle, rather than any of the other theories of contract law. The $B M W$ Case shows this in its plaintiff's use of negligence and agency theories.

The BMW Case. Cullen paid an auto dealer for a car which was never delivered. The manufacturer, BMW, had terminated its relationship with the dealer due to customer complaints and financial irregularities, but he continued to sell from his inventory of BMW cars and to use the BMW logo. (Cullen v. BMW, 1980)

BMW did not give actual authority to the dealer, nor, one may argue, did it give apparent authority by its manifestations. Rather, after terminating what might have been

\footnotetext{
${ }^{31}$ Restatement, $\S 8 \mathrm{Bc}$, which notes that nonfeasance also estops a landowner who fails to prevent someone else who believes himself the owner from making improvements on it (Restatement of Restitution, 40, 43) or a landowner who fails to prevent someone else from selling his land to a bona fide purchaser (Restatement of Torts, $§ 894,(2)$ ).
} 
apparent authority, BMW neglected to stop the dealer from continuing to use the BMW name, and hence, the Court said, was estopped from denying agency.

\section{Ratification}

Ratification, the fifth source of liability, occurs when the principal assents to an agreement after it is made by someone who lacks authority. Ratification is similar to actual express authority, because when the principal ratifies the agreement he is saying that he sees no mistake worth the cost of renegotiation. The principal will be the leastcost avoider for the same reason as when the agent has actual express authority. Even ratification has its nuances, however, as shown in the following case of ratification by silence.

The Silent Client Case. The State of New York appropriated land owned by Hallock and Phillips, with payment, and they took the matter to court. They told their lawyer not to settle the case in a particular way, but the lawyer did anyway. Phillips stood by without objecting at the settlement conference, and Hallock waited two months to object. Was Hallock bound by the settlement? (Hallock v. State, 1984)

The Court ruled that Hallock was bound by the settlement, and based its decision on ratification, even though it might have emphasized that New York court rules (in contrast to the Pennsylvania statute in the Lawyer Madnick Case) required that attorneys at pretrial conferences have authority to bind their clients to settlements.

Again, we see the difficulty of naming the appropriate legal doctrine. This could be ratification, agency by estoppel, apparent authority, or even, based on the New York court rules, implied actual authority or inherent agency power. Yet it is easy to see that Hallock was the least-cost avoider.

\section{Inherent Agency Power}

The last source of liability, inherent agency power, returns us to Watteau $v$. Fenwick, here abstracted as Illustration 5.

Illustration 5: Express Instructions Violated. $P$ buys $A$ 's tavern and hires him as manager, instructing him not to buy cigars for the tavern. $A$ orders cigars for the tavern anyway, from $T P$, who believes $A$ to be the owner. Must $P$ honor the agreement?

$A$ lacks actual authority to buy cigars, because of $P$ 's instructions, and lacks apparent authority because $T P$ does not believe $A$ to be $P$ 's agent. $P$ 's liability is based on inherent agency power: $A$ has been put into a situation, where he can impose losses on third parties unless $P$ is made liable. ${ }^{32}$

\footnotetext{
${ }^{32}$ Note that $A$, as well as $P$, is liable to $T P$ also in situations where inherent agency power is invoked because of an undisclosed principal. This is different from most of the other sources of authority, though $A$ may also be liable in cases of estoppel, and this will be discussed in Section
} 
The least-cost avoider principle reaches the same result, because $P$ can control $A$ more cheaply than can $T P$. Not only do the arguments made earlier for $P$ 's lower cost of mistake avoidance apply, but the fact that $P$ is undisclosed strengthens the argument because $T P$ does not even realize there is an agency problem.

Agents making false representations, the situations where inherent agency power is applied, create a variety of special cases (see Section 4.B and 5.C), not all of which isolate the principal as the least-cost avoider. The least-cost avoider principle is a more coherent explanation for how courts make decision.

Thus, every one of the six sources of liability can be justified by the least-cost avoider principle. It can be difficult to decide for a given case which of the six sources of agent authority is decisive, but it is often easier to decide who is the least-cost avoider. That idea runs through all six principles, and gives a single efficiency justification for all of them.

\section{Tort and Agency Doctrines Compared}

As discussed earlier, the agency law of contracts is really a mix of tort and contract. There is damage that might occur, and two parties (plus the agent) who might take care to prevent it, as in tort. As in contract, the efficiency loss from having the wrong default law is usually limited to the transaction cost of writing an improved rule into the contract--- but sometimes, as in tort, this cannot be done, because it is the wayward agent who would have help with doing the writing.

A natural question is how the six agency doctrines relate to tort doctrines such as contributory negligence and strict liability. In tort terms, we may think of the principal having caused injury to the third party by allowing the execution of an agreement whose non-enforcement will be to the third party's detriment. (It will not hurt the analogy that the reverse is equally plausible, since here, unlike in tort, there is no actual injury until the court decides whether or not to enforce the contract.)

Tort doctrines look to how the carelessness of one or both parties led to the damage. Being careless is called being "negligent", which is equivalent to exercising inefficiently little care under the Hand Rule, but might be defined under some other standard such as industry custom (see Epstein, 1992). Suppose the third party, and only the third party, was negligent. In tort, the principal is liable for the damage only under the doctrine of strict liability. In agency, this corresponds to the doctrine of actual authority. The agent has actual authority to execute the agreement, then it does not matter how careless the third party was in checking that authority: the agreement is a contract and the principal must honor it.

5. This is also different from vicarious liability, to which inherent agency power is often analogized, since the agent is not liable for his torts. 
If it is only the principal that is negligent, then he is liable under tort, and similarly under agency. This is the essence of apparent authority: the principal has given the agent opportunity to deceive the third party, and so the principal must honor any agreements made. Inherent agency power would seem to fit under the same heading: the principal's lack of care has led to the mistaken agreement, and the third party cannot be expected to compensate.

If neither party is negligent, then tort doctrine ordinarily lets losses lie where they fall - giving the third party no relief, in our framework. This is efficient because to allow access to the courts for relief would result in excess care by one or both parties, they already having had sufficient incentive to exercise efficient care. If, for example, the agent has so cleverly forged his credentials that efficient monitoring by the principal and efficient checking by the third party would not detect it, then he does not have authority to make the contract, and the courts will not enforce it.

In tort, as in agency, finding the efficient law is most difficult when both parties have taken insufficient care. Under tort, the doctrine of contributory negligence would bar relief for the third party if not just the principal but he himself were negligent in monitoring the agent. This might be modified by the comparative negligence doctrine, under which the costs of the mistake are shared (see, e.g., Li v. Yellow Cab Co., 1975, or Landes and Posner, 1987, pp. 80-84), or by the last clear chance doctrine, under which the principal would still be liable if he had the last opportunity in time to prevent the harm (see, e.g., Belton v. Washington Metro. Area Transit Auth., Williams, J., 1994, or Landes and Posner, 1987, pp. 92-95).

Comparative negligence has no analog in agency law, though Whincop (1997) has proposed that costs be split according to the degree of carelessness of the principal and the third party. The last clear chance doctrine, however, has clear analogs in authority by estoppel and ratification. The essence of these is that whatever may have contributed to the mistake earlier, if the principal fails to correct the problem when he could easily do so then the court will force him to honor it. (The contract doctrine of mitigation of damages is also similar in flavor.) We will also see examples below of the last mover bearing the cost of mistakes - examples in which the decisive consideration is the third party's lack of care at the time of contracting.

\section{B. When Should the Third Party Bear the Cost of Mistaken Contracts?}

In the illustrations in Section 4.A, the principal was the least-cost avoider of error, as one would usually expect, given his control over the identity and incentives of the agent. "Usually" is not "invariably", however. The third party has the advantage of being present at the time of contracting, and so has available at low cost additional information relevant to whether the purported agent is taking a wrong action.

\section{Care to Check Authority}


Illustration 6: Not Checking Authority Carefully. "P tells TP that $A$ is authorized to buy sheep for him when the market price of wool in another country has reached a certain point. TP sells sheep to $A$, relying upon $A$ 's untruthful statement that the price of wool has reached the specified point." ${ }^{33}$ Is $P$ bound by the agreement? (Restatement, $\S 168$ )

According to the Restatement, $P$ is not bound in Illustration $6 . T P$ is the leastcost avoider, because his cost of verifying $A$ 's claim is lower than the cost to $P$ of ensuring that $A$ does not make false claims. $P$ does have means to prevent the false claims--- through threat of discharge, if nothing else--- but the cost for $T P$ to check the claims is lower.

The outcome would be different if it were more costly for $T P$ to discover the information on which $A$ 's authority relies. We have already seen in Watteau v. Fenwick that secret instructions do not protect $P$. This is equally true of information known to $A$ but not to $P$ or $T P$. If $P$ authorizes $A$ to buy one sheep, and tells $T P$ that $A$ may be coming by to do so, then $P$ is bound by $A$ 's purchase from $T P$ even if $A$ had previously terminated his authority by buying a different sheep from someone else (Restatement, $\$ 171)$.

It is crucial whether the information available to the third party should lead him to take special care to check authority, as seen in the following three cases, in which a bailee improperly disposes of goods entrusted to him. ${ }^{34}$

The Delicatessen as Art Gallery Case. Porter loaned a painting to Von Maker, who hired deli employee Wertz to sell it to Brenner via dealer Feigen. Porter sued Feigen for return of the painting. Should he win? (Porter v. Wertz, 1979)

The Court decided, however, that Wertz was not an art merchant in the sense of the Uniform Commercial Code, and that Feigen ought to have taken the precaution of telephoning one of the numbers Wertz gave him, which would have revealed his employment at the delicatessen. ${ }^{35}$ Feigen argued that industry practice in the art business

\footnotetext{
${ }^{33}$ See the similar Mussey v. Beecher (1849). The defendant authorized his agent to buy up to $\$ 2,000$ in books for his store. The agent bought more than that amount, and ordered even more from the plaintiff, falsely telling the plaintiff that the limit was not yet exceeded. Judge Shaw ruled for the defendant.

${ }^{34}$ Bailment is the rightful possession of goods by someone who is not their owner. A bailee is "a species of agent", his duty limited to taking care of certain items of movable property (Black's, p. 141). Black's is loose here. Some agents are bailees, but not all bailees are agents. "While a bailment is frequently incident to the relation of principal and agent, such relation does not exist where the bailor has no control over the bailee, even though the acts of the bailee benefit the bailor." (Jones v. Taylor, 1966, at 186)

${ }^{35}$ Under the Uniform Commercial Code, giving temporary possession to a merchant blocks recovery from a third party if the merchant sells the good. "(2) Any entrusting of possession of goods to a merchant who deals in goods of that kind gives him power to transfer all rights of the entruster to a buyer in ordinary course of business. (3) 'Entrusting' includes any delivery and any acquiescence in retention of possession regardless of any condition expressed between the parties to the delivery or acquiescence and regardless of whether the procurement of the entrusting or the
} 
was to not inquire into the backgrounds of one's customers. The Court rejected this, saying,

The Feigen claim that the failure to look into Wertz's authority to sell the painting was consistent with the practice of the trade does not excuse such conduct. This claim merely confirms the observation of the trial court that 'in an industry whose transactions cry out for verification of title it is deemed poor practice to probe'. Indeed, commercial indifference to ownership or the right to sell facilitates traffic in stolen works of art. Commercial indifference diminishes the integrity and increases the culpability of the apathetic merchant. ${ }^{36}$ (at 258).

The following case makes much the same point: the third party has a duty to investigate suspicious sales.

The New Jersey Diamond Case. Wolf consigned a diamond ring to auction company Brand with written instructions not to sell it without permission. Brand borrowed $\$ 4,000$ from Nelson, using the ring as collateral for that loan and for a previously bounced check to Nelson. Nelson then purchased the ring from Brand in return for cancelling the loan, but without a written bill of sale. He consigned the ring back to Brand, who returned it to Wolf. Can Nelson recover the ring? (Nelson v. Wolf, 1950)

Nelson did not recover the ring in this pre-U.C.C. case, because although he did not know all these facts, (a) he knew Brand needed money and had bounced a check, (b) he knew Brand had trouble repaying the loan, (c) the lack of a bill of sale was suspicious, and (d) he was not an ordinary customer. Contrast this what happened three years later:

The New York Diamond Case. Diamond merchant Harry Winston sent a diamond ring to auction company Brand for examination, with written instructions not to sell it without permission, and allowed Brand to display it publicly. Brand then sold it to Jane Zendman. Does she own the ring? (Zendman v. Harry Winston, 1953---yes, it's the same auction company as in the New Jersey Diamond Case.)

The Court gave title to Zendman, since she, an ordinary customer, had no reason to be suspicious. In addition (important in this pre-U.C.C. case), Winston had allowed public display of the ring together with Brand's other merchandise. The principal had not taken care, and the third party could not, so the principal bore the loss. ${ }^{37}$

It is an easy step from these cases to ones involving stolen goods, a topic to which some of the leading scholars in law and economics have given attention (e.g. Landes and Posner, 1996, and Levmore, 1987). There, the law must decide whether to give

possessor's disposition of the goods have been such as to be larcenous under the criminal law."

(U.C.C. \$2-403)

${ }^{36}$ Porter v. Wertz (1979) at 258. This reasoning is similar to the issue of whether industry custom is a defense in tort cases such as Learned Hand's The T.J. Hooper (1932). Epstein (1992) explores the difference between tort and contract on the issue of whether industry custom should be a defense against negligence.

${ }^{37}$ The UCC changed the law by not requiring a showing of lack of care by $P$., perhaps changing the common law rule because telephone had made $P$ 's care cheaper. 
possession of stolen goods to the original owner or to someone who bought them from a thief, and the efficient rule depends on how the effort of each party could be used to deter the theft. ${ }^{38}$

\section{The Third Party Has Immediate Information about the Transaction}

A second reason why TP may be the least-cost avoider is that he is on the spot at the time of contracting and can observe the agent's behavior.

Illustration 7: Incapacity of the Agent. $P$ hires $A$ as an agent to buy goods from $T P$. While intoxicated, $A$ orders the wrong goods from $T P$, who knows that $A$ is intoxicated. Must $P$ pay for the goods?

$P$ should not have to pay for the goods, because it is $T P$ who has the least cost of monitoring $A$ 's sobriety. ${ }^{39}$ If $T P$ has no way of knowing that $A$ is intoxicated, the answer is more difficult. ${ }^{40}$ Contract law does not premise lack of capacity on the knowledge of the other party of that lack. Here, however, $P$ stands behind $A$, and can take measures to prevent him from contracting while intoxicated. If $P$ has hired a habitual drunkard as his agent, $P$ surely should bear the loss from $A$ 's frivolous agreements.

\section{Collusion between Agent and Third Party}

A third reason to release the principal from liability is if the third party colludes with the agent against him.

Illustration 8: Collusion with the Agent. "TP sells a horse to A, P's authorized agent. TP represents the horse to be sound. $A$ knows the horse to be unsound. $P$ does not have this knowledge." Is $P$ bound by the agreement? (Restatement, $§ 144$ )

The Restatement bases the result in Illustration 8 on the additional fact, unmentioned in Illustration 8 , of whether $T P$ and $A$ have colluded. Note first that $T P$ 's misrepresentation is not the cause of the erroneous purchase, which it would have been had he been selling directly to $P$, because $A$ was not fooled by it. Therefore, if there was no collusion between $T P$ and $A, P$ would be bound by the contract; he could have gone to the trouble to hire a more responsible agent than $A$. Or, it might be that in $A$ 's judgement, $T P$ 's interests are served by buying an unsound horse. If $T P$ had been colluding with $A$,

\footnotetext{
${ }^{38}$ Carrying the idea further still, it has been suggested that criminal penalties should be set to less than the cost of the theft (Hylton, 1996; Friedman, 1996), or that victim carelessness should be a defense for the criminal (Ben-Shahar and Harel, 1995), both of which would encourage victim precaution.

${ }^{39}$ Lack of capacity is a standard formation defense for breach of contract. See the Restatement (Second) of Contracts, $\$ 18$.

${ }^{40}$ Restatement, $\$ 122$ seems to say that the contract remains invalid: the agent's authority to contract ends after an event which "deprives the agent of capacity to make the principal a party to it."
} 
on the other hand, the contract would be invalid, because (a) the likelihood that $A$ is acting in $P$ 's interests drops sharply, and (b) $T P$ could have prevented the harm by refraining from colluding with $A$, a very low cost to $T P .^{41}$

The unenforceability of corrupt agreements might be based on any of a number of grounds, including fairness, prevention of gain to evildoers, and the corruption of public morality, but, interestingly enough, the U.S. Supreme Court chose to base it on legal doctrine and economic efficiency, in a case involving bribes to corporate officers to choose a particular route for a railroad:

"Indeed, the law is general that agreements upon pecuniary considerations, or the promise of them, to influence the conduct of officers charged with duties affecting the public interest, or with duties of a fiduciary character to private parties, are against the true policy of the State, which is to secure fidelity in the discharge of all such duties. Agreements of that character introduce mercenary considerations to control the conduct of parties, instead of considerations arising from the nature of their duties and the most efficient way of discharging them. (Justice Field, Woodstock Iron Company v. Richmond and Danville Extension, 1889, at 662)

More generally, Restatement, $\S 165$ releases the principal from liability to third parties for contracts made by agents when the third party knows that the agent is not acting for the benefit of the principal. This would not always release the principal from liability from a contract obtained by bribery--- maybe the third party needs to bribe the agent to do his job properly!--- but it will cover most cases. Thus, the third party is made responsible for monitoring the agent if the direct cost of so doing is zero.

George Cohen (2000, at 28) has made collusion the basis for an alternative to the least-cost avoider principal as an explanation for agency law, arguing that "...the law of contractual authority can largely be understood as an attempt by courts to draw a line between situations in which it is appropriate to presume principal-agent collusion, and situations in which it is more appropriate to switch the presumption to agent-third party collusion." I just discussed agent-third-party collusion, and suggest that its treatment is an example of the least-cost avoider principal at work. This is generally true, because where there is a possibility that the agent and principal might collude, agreeing that the principal will be liable for the agent's agreements where convenient but not otherwise, the third party can always overcome the collusion by incurring the transaction cost of checking the agent's formal authority. The difference between the two theories-leastcost avoider and collusion - is that collusion is a subset of least-cost avoider. If there is collusion, whoever is colluding has the least cost of forestalling contracts that are inefficient ex ante. The least-cost avoider principle, however, also applies to situations where there is no collusion - for example, where the agent absconds with all the funds, to the benefit of neither principal nor third party, or where the agent simply makes mistakes with no strategic intent. Collusion is a better explanation for agency contract law only if

\footnotetext{
${ }^{41}$ Another example of the idea that collusion releases the principal from an agreement can be found in international law. Restatement (Third) of Foreign Relations, §331(1)(c) allows a government to invalidate an international agreement entered into by a corrupt agent.
} 
such examples are much rarer than cases where collusion is the chief danger-something I believe to be untrue.

\section{Obvious Agent Malfeasance}

A fourth reason to release the principal from liability is if the agent's malfeasance should be obvious to the third party from the terms of the agreement. ${ }^{42}$

Illustration 9: Obvious Agent Malfeasance. $P$ authorizes $A$ to buy a refrigerator for him. $T P$ has listed a refrigerator for sale at $\$ 400$, but $A$ offers $\$ 700$ if it can be delivered slightly more quickly. $T P$ knows that $A$ is an agent for $P$ and that $P$ would not value speed of delivery at $\$ 300$. Is $P$ bound by the agreement?

According to the Restatement, "Unless otherwise agreed, authority to buy or sell with no price specified in terms includes authority to buy or sell at the market price if any; otherwise at a reasonable price." (Restatement, §61) This implies that $P$ is not bound by the agreement in Illustration 9 . TP has the least cost of controlling the agent's misbehavior because he is on the spot, unlike $P$. The price of $\$ 700$ is so excessive that it should be easy for $T P$ to see that $A$ is misrepresenting his authority from $P$.

If the price paid had only been $\$ 450$, the mistake would not be so clear. An extra $\$ 50$ is not an unreasonable premium for speed, and it is not easy for TP to tell that $A$ is misbehaving. The cost to $P$ of preventing overpayment, on the other hand, is little different whether the amount is $\$ 50$ or $\$ 300$. The least-cost avoider principle suggests that $P$ should be liable for small mistakes, but not for large ones. ${ }^{43}$ The following case similarly involves an offer that is too good to be true.

The Corrupt Treasurer Case. Kraft, the treasurer of Anaconda, guaranteed on its behalf repayment of a loan made by Haggiag via his company GOF to Robin, a company owned by one Reisini. Reisini and Kraft were in collusion, contrary to the interests of Anaconda. Kraft did not have actual authority to guarantee the loan, but he managed to fool six banks into extending credit of various kinds to Reisini. The loan went bad. Can GOF collect from Anaconda? (General Overseas Films, Ltd. v. Robin Int'l, Inc., 1982)

The Court recognized that Haggiag could not have acquired more information about Kraft's authority at reasonable cost, since, "... had Haggiag inquired further into Kraft's authority, he would not have discovered anything to cast doubt upon the transactions' propriety, since Kraft was the person at Anaconda authorized to produce evidence as to both the authority to transact business on behalf of Anaconda and any changes in that authority." (at 690) Haggiag lost his suit, however, because the loan

\footnotetext{
${ }^{42}$ A plaintiff "claiming reliance on (an) agent's apparent authority must not fail to heed warning or inconsistent circumstances." (Williston, 1957, at 227)

${ }^{43}$ Recall Restatement $\$ 165$, discussed earlier, which says that the principal is not bound when the third party knows the agent is not acting for the principal's benefit. There is no duty for the third party to inquire more than superficially, but egregious misbehavior should be detected by the third party.
} 
guarantee was not in Anaconda's usual line of business. The six banks that also trusted Kraft all took more precautions and sought more explanation's for Anaconda's interest, though it is still not clear whether they would have collected from Anaconda had their cases not settled out of court.

What these various cases show is that the third party is indeed sometimes the least-cost avoider, and courts recognize this in deciding whether doctrines such as apparent authority apply.

\section{The Undisclosed Principal Problem}

This variety of illustrations has shown that the least-cost avoider principle can be useful in guiding agency law. This section will apply it to one of the most vexing areas of agency law: the undisclosed principal problem.

\section{A. The Undisclosed Principal Problem}

The undisclosed principal problem arises when an agent makes an agreement with a third party who does not realize that the agent is acting for a principal rather than on his own behalf. The question then arises of whether the third party has a legal claim against the principal as well as against the agent. Watteau v. Fenwick is particularly dramatic because the agent acted against the express wishes of the principal, but the problem exists even if the agent is obedient, as in Illustration 10.

Illustration 10: The Undisclosed Principal Problem. A agrees to buy goods from TP. A represents $P$, unknown to $T P$. Is $P$ bound by the agreement?

Ordinary contract law says that $A$ and $T P$ are bound by the contract. Agency law agrees, but says that $P$ is also bound, which is difficult to justify under the usual jurisprudential theories of contract law. ${ }^{44}$ The rule violates the standard will theories of contract. As the Restatement says,

The undisclosed principal rule appears to violate basic principles of contract law. The relation between principal and a person with whom the agent has made an authorized contract is spoken of as contractual, although by definition there has been no manifestation of consent by the third person to the principal or by the principal to him. (Restatement, §186)

The rule is no better explained by the bargain theory or reliance theory of contract. The bargain theory looks to whether the two parties bargained with each other.

\footnotetext{
${ }^{44}$ This discussion is drawn from Barnett (1987), who provides references to the case law and evidence of the discomfort of common law scholars with the undisclosed principal rule. Barnett briefly discusses efficiency theories of contract, but objects to them as not providing a normative theory of contractual obligation.
} 
$T P$ did not knowingly bargain with $P$, and making $P$ liable provides $T P$ with a benefit for which he did not bargain. The reliance theory looks to whether the two parties reasonably rely on each other's promises. TP does not rely on $P$ 's promises, because he does not know that $P$ exists. ${ }^{45}$

An efficiency theory of contract law has an easier time explaining the undisclosed principal rule. In Illustration 10, the contract is desirable from the point of view of both $P$ and $T P$, unless we add special details such as an unwillingness of TP to sell to $P$ at as low a price as to $A$ (about which more in Section B). TP is getting a windfall by this contract, because not only is $A$ bound to pay him, but so, unknown to $T P$, is $P$. Thus, there is no puzzle at all from the point of view of efficiency.

The least-cost avoider principle enters usefully if we add agent malfeasance to the illustration. If $A$ has an undisclosed principal, then $T P$ 's cost of preventing $A$ from making an inefficient contract is greater than $P$ 's. $T P$, who does not even know that $A$ is an agent, should be allowed to take even less care than if he knew $A$ were an agent. Consider again Illustration 9 , in which $A$ pays $\$ 700$ for a refrigerator that normally costs $\$ 400$. The Restatement seems to indicate that $P$ is released from obligation regardless of whether he is disclosed or undisclosed. The least-cost avoider principle says that the court should think harder about releasing $P$ if he is undisclosed, because $T P$ has less reason to be suspicious and to investigate. Without knowing that $A$ is an agent, $T P$ has no reason to doubt that $A$ has some personal reason for paying a large premium for speedy delivery.

The rule that undisclosed principals are bound by their agents' contracts also usefully encompasses situations in which the agent has used the resources of the principal to appear wealthy and dependable. In such situations, a contract between $A$ and $T P$ without obligation to $P$ could be mistaken, because $T P$ would falsely believe that $A$ was creditworthy. Watteau $v$. Fenwick is one such case: the manager seemed more creditworthy because he appeared to own the tavern. Indeed, the very act of placing an order may make an agent seem more dependable. If an individual orders ten thousand dollars worth of replacement parts for a power plant, it is natural to suppose that he is acting on behalf of a larger business.

That $T P$ receives a windfall because he did not rely on $P$ 's credit when entering into the contract does raise concerns, however. If $T P$ has the option of enforcing the contract against $P$, he has gained an advantage for which he had not bargained with $A$ : if $A$ is insolvent, TP can sue $P$ instead. This windfall matters not only for fairness but efficiency, as the various forms of Illustration 11 show.

Illustration 11.1: No Principal. A, who owns no assets, orders goods on credit from TP which cost $\$ 90$ to produce. If there is no recession, $A$ can resell the goods for $\$ 105$,

\footnotetext{
${ }^{45}$ Barnett (1987) shows that his own "consent theory" of contract does explain the common law rules of the undisclosed principal problem. This theory looks to whether (a) the subject of the contract is a morally cognizable and alienable right owned by the transferor and (b) the transferor manifests his consent to transfer the right.
} 
while if there is a recession, which occurs with a 10 percent probability, the goods are worth nothing. The contract takes the form of a contract price of $\$ 101$, and $A$ breaches if a recession occurs.

Illustration 11.2: Principal and Windfall. The same as 11.1, except: $A$ is backed by undisclosed principal $P$, who must honor the contract and will not become insolvent in doing so. TP believes the probability that $A$ is backed by an undisclosed principal is negligible and so still insists on a contract price of $\$ 101$. A contract price of $\$ 101$, would yield negative profits for $P$, so no agreement is reached.

Illustration 11.3: Principal, No Windfall. The same as 11.2 except: The legal rule is that $P$ is not a party to the contract, and so need not pay damages if $A$ breaches. A contract price of $\$ 101$ would yield positive profits for $P$, and so agreement is reached.

In each of the variants it is efficient for $T P$ to sell the goods to $A$, but in 11.2 , in which the undisclosed principal is bound, agreement is not reached. He would authorize $A$ to make the contract if undisclosed principals were not liable, but not otherwise. Thus, there is indeed a potential efficiency loss associated with making undisclosed principals liable on contracts. Some mutually beneficial contracts will not be made, because TP does not know how valuable the contract being offered to him is.

Could the windfall be avoided by special contract terms? A maxim of the law and economics of contract is that if transaction costs are low, the parties will customize their contract regardless of the legal default rule, so an inefficient default rule can cause only a limited amount of harm. This might seem to be a way out of the undisclosed principal problem, as in Illustration 12.

Illustration 12: Special Contract Terms. A agrees to buy goods from TP, but the contract specifically excludes any liability on the part of anyone but $A$ and $T P$. $A$ represents $P$, unknown to $T P$. Is $P$ bound by the agreement?

$P$ has no obligation to TP here (Restatement, $§ 189$ ), but it may be difficult to write a contract of this kind because asymmetric information creates serious trouble for this contract maxim. ${ }^{46}$ If $A$ proposes a term exempting other parties from liability, TP can deduce that $A$ is backed by a principal, which is information that $A$ may not wish to disclose. Very often there are legitimate business reasons why $P$ wants his involvement to be secret. He may, for example, be trying to buy up parcels of land to combine for a project such as a shopping center and needs to avoid being held up by the last purchaser, who could extract an enormous price for the parcel needed to complete the project, or be a mining company which has at considerable expense decided that a parcel of land has mining potential, but does not want to deliver this information as a windfall to the current owner by trying to purchase the land under the mining's company's own name. If most agents wished to exempt their principals from liability, it would be important to make this exemption the default rule, or perhaps even to make it mandatory.

\footnotetext{
${ }^{46} \mathrm{~A}$ number of articles have appeared in recent years showing how parties may be reluctant to propose special contractual terms, or to object to adding terms, because such actions would reveal their private information. See Ayres and Gertner (1989) and Spier (1992).
} 
Whether because of the windfall problem or for some other reason, there is one class of undisclosed principal cases where American courts have usually exempted the principal from liability: that where credit is extended to the agent. This class is described in Illustration 13.

Illustration 13: Principal Pays but Agent Breaches. A agrees to buy goods from $T P$, and $T P$ delivers the goods. Unknown to $T P, A$ is an agent for $P$. $P$ pays $A$ the money for the goods, but $A$ becomes insolvent before paying $T P$. Can $T P$ sue $P$ for payment?

Traditionally, American courts would deny $T P$ the right to sue $P$, on the grounds that $T P$ relied only on $A$ 's credit, but English courts and the Restatement, would give TP the right to sue (Barnett, 1987, at 1973, 1984; Restatement, §208). The least-cost avoider principle leads to the English rule. $P$ has the least cost of inducing $A$ to make an efficient contract, and also has the least cost of preventing $A$ from losing the payment money before transferring it to $T P$.

Thus, the standard rule, which makes the undisclosed principal liable on his agent's contract, makes perfect sense if efficiency is the goal and the least-cost avoider principal is applied. Ordinarily such a contract will be efficient, and if a mishap occurs, it is the principal, not the third party, who was in the best position to have monitored the agent.

\section{B. Liability of the Third Party to the Principal}

A different part of the undisclosed principal problem is the obligation of the third party to the principal. Should $T P$ be bound contractually to a party he did not know existed? Illustrations 14 and 15 contrast two situations in which $T P$ would have regrets about the contract if he knew that $P$ existed.

Illustration 14: Inadvertent Sale to an Enemy. TP agrees to sell goods to $A$, who, unknown to $T P$, is an agent for $P$. TP and $P$ are bitter enemies, and $T P$ would never willingly sell goods to $P$, as $A$ and $P$ know. $T P$ later discovers that $A$ is acting for $P$. Is $T P$ bound by the agreement?

Illustration 15: Inadvertent Sale to a Rich Buyer. TP agrees to sell goods to $A$, who, unknown to $T P$, is an agent for $P$. $P$ is very rich, and $T P$ would have held out for a higher price if he had known $P$ was interested in the goods. $T P$ later discovers that $A$ is acting for $P$. Is $T P$ bound by the agreement?

In both illustrations, $T P$ would have been willing to sell to $A$ at the specified price, but not to $P$. Where they differ is in $T P$ 's motivation. In Illustration $14, T P$ 's motive is real, rather than redistributive. TP's utility from holding the goods himself is greater than the sum of his utility from the sale price to $P$ plus the disutility of knowing that $P$ has bought the goods. The result is analogous to when a purchaser buys a defective product: 
the utility he expects from the transaction is less than the utility he receives. Thus, there is a case for invalidating the sale. ${ }^{47}$

In Illustration 15, on the other hand, $T P$ 's motive is redistributive. $T P$ 's utility from holding the goods himself is less than his utility from the sale price to $P$, and he would prefer the agreed sale price to not selling the goods at all. TP is dissatisfied, but that is only because he could have received an even higher price if he had known that $P$ was the ultimate buyer. Thus, the transfer of the goods from $T P$ to $P$ is allocatively efficient, and there is no reason to invalidate the agreement.

Even in Illustration 14, however, it is not clear that exempting $T P$ from liability for contracts with undisclosed principals is advisable. First, there is the difficulty that if the law exempted TP from liability, $P$ could simply contract with $A$ to buy the goods and $A$ could buy the good from $T P$ on his own authority, without risk to either $P$ or $A$ since they are protected from each other by their contract. Thus, exempting $T P$ from liability to $\mathrm{P}$ as an undisclosed principal would just increase $P$ 's transaction costs slightly. The obvious solution to this possibility is for $T P$ to add a special contractual term forbidding resale to $P$ or, if the legal default rule is that third parties are not bound to undisclosed principals, by adding a clause to override that default if the hated $P$ is the undisclosed principal. Unlike in Illustration 12, where a similar clause faced the difficulty that it might signal the existence of an undisclosed principal, here the clause would be proposed by the third party, and so does not disclose any information except his dislike for $P$, which he does not mind disclosing.

A similar clause could be inserted in the contract of Illustration 15, to prevent an agent from acting on behalf of a rich principal or reselling to one. Airlines do this when they forbid one customer from using a ticket bought by another apparently on his own behalf, and movie theatres would no doubt start doing this if they found that ordinary customers were hiring students or senior citizens to buy cheap tickets on their behalf.

Thus, there is a strong case for making third parties liable to undisclosed principals, subject to their right to override the legal default in general or with regard to specific principals.

\section{An Agent Acting Outside of His Authority}

Section 4.A discussed why the principal should be liable when the agent has various categories of authority. A final puzzle in the undisclosed principal problem is what should happen when an undisclosed agent acts without authority. Should the

\footnotetext{
${ }^{47}$ Steffen (1977) at 188 says that if the third party has once refused to deal with the principal, the principal may not circumvent the refusal by using a secret agent, according to most courts. When the third party's desires are less objectively manifested, courts are less likely to intervene. An example is Kelly Asphalt Block Co. v. Barber Asphalt Paving Co. (1914), in which Judge Cardozo held for a buyer who had remained an undisclosed principal because he suspected a competitor would refuse to deal with him.
} 
undisclosed principal be liable? The question at first seems trivial--of course he should not--but the principal might have the least cost of preventing mistakes by the agent even when the mistakes are unconnected with the principal's purpose in hiring him. Illustration 16 is an example.

Illustration 16: An Agent Acting on his Own Behalf. "P authorizes $A$ to purchase a particular horse in $A$ 's name and gives $A$ the money to do so. $A$ purchases the horse on his own credit, without disclosing $P$ 's existence, intending to abscond with horse and money, which he subsequently does." (Restatement, §199). Is $P$ liable to TP, the seller of the horse?

If $P$ were a disclosed principal and $A$ bought the horse on $P$ 's credit, $A$ 's motivation would not matter and $P$ would be liable. That would make sense, because $P$ could control $A$ at lower cost than $T P$.

Since $P$ is undisclosed, however, Illustration 16 is hard to distinguish from the ordinary undisclosed principal problem of Illustration 10. In both, the issue is whether $P$ should be liable for a mistaken contract when $A$ cannot pay, both $P$ and $T P$ have lost wealth, and $T P$ does not know of $P$ 's existence. Why should $A$ 's motivation matter?

According to the Restatement, $P$ is not liable, because $A$ is not acting as his agent. Let us see why this makes sense. Consider $P$ 's incentives in deciding whether to hire $A$. In Illustration 16, where $A$ is acting on behalf of $P$, the contract would not have been made had $P$ not set the process in motion. If contracting by means of an agent sometimes leads to harm, $P$ ought to bear the cost, or he will be too willing to use an agent. That is what happened in Illustration 10, where $A$ would never have approached $T P$ to buy a horse if $P$ had not hired him as an agent. $P$ 's hiring of an agent who might lose money, go insolvent, or otherwise ruin transactions is somewhat under $P$ 's control and is not at all under $T P$ 's. Illustration 16 is different because $P$ 's hiring of $A$ in no way caused the harm. If $P$ had never hired $A, A$ could still have done the same thing, agreeing to buy the horse from $T P$ and absconding. That $A$ 's action is to abscond with a horse is irrelevant; if $A$ had taken $P$ 's money and absconded with $T P$ 's bicycle instead, the problem would be essentially the same. Only if $A$ 's ability to credibly make the contract to buy the horse depended on his relationship with $P$-- a situation like Watteau $v$. Fenwick--should $P$ be liable. Otherwise, the harm does not result from $P$ 's desire to buy a horse using an agent, and it would be inefficient to impose an extra cost on that activity by making $P$ liable for $A$ 's misdeeds.

The point that the principal should not be liable for harm caused by an agent acting without authority can be applied more generally. Although it may offend everyday notions of fairness, one might argue on efficiency grounds that the principal should be liable for harm caused by the agent even if all of Section 2's six sources of liability are lacking, because the principal can still control the agent by means of his contract.

This is the same argument made for strict liability, where the moral fault may lie with the consumer who misuses a product, but efficiency conceivably requires the liability to be put on the seller. Let us start with agent torts rather than contracts. The 
legal rule of vicarious liability is that the principal is liable only for torts the agent commits in the course of employment (Restatement, §219). Imagine going a step further by making the principal liable even for the agent's torts while the agent is on holiday at the beach. The justification would be that the principal can control even those torts by threatening to fire the agent if they occur. Making the principal liable would be distortionary, however, because it would tend to deter the hiring of agents. The extra liability on the principal is like a tax on hiring agents. Thus, it is not enough to discover that the principal is the least-cost avoider in controlling agents; one must also decide whether imposing the cost of avoiding the harm might deter principals from hiring agents in the first place.

\section{Concluding Remarks}

I have here analyzed the central doctrines of agency as they apply to contracts made by agents, and find the common law generally sensible in terms of economic efficiency. Scholars will find the Restatement of Agency a stimulating source of many other difficulties that arise when one person acts for another, and there is ample room for economic analysis of similar problems that arise when one person acts for another in other areas of the law such as partnership, criminal conspiracy, and marriage.

My unifying theme has been the view of the agent as an error-prone means to reduce transaction costs, a role in which he is useful to both parties in the transaction, the principal and the third party, both of whom can take care to prevent the errors. This view leads naturally to the idea that the liability rules should try to provide each of the two transactors with incentive to monitor the agent. The least-cost avoider principle reduces the complexity of assigning liability, which must otherwise be done by applying a number of distinct doctrines such as apparent authority and inherent agency power. Indeed, the decisions of the common law, while doctrinally somewhat confused, make considerable sense when viewed as allocating blame to the party who was the least-cost avoider of agent mistakes or malfeasance. The idea also gives insight into the undisclosed principal problem. Binding an undisclosed principal to pay for contracts made by agent, though a windfall for the third party, becomes much more reasonable in light of the principal's lower cost of preventing inefficient agreements from being made by the agent. 


\section{References}

American Law Institute. 1933. Restatement of the Law of Agency, St. Paul, Minnesota: American Law Institute.

------. 1937. Restatement of the Law of Restitution: Quasi Contracts and Constructive Trusts, St. Paul, Minnesota: American Law Institute.

------. 1958. Restatement of the Law, Second: Agency 2d., St. Paul, Minnesota: American Law Institute.

------. 1977. Restatement of the Law, Second: Torts 2d., St. Paul, Minnesota: American Law Institute.

------. 1981. Restatement of the Law, Second: Contracts 2d., St. Paul, Minnesota: American Law Institute.

------. 1986. Restatement of the Law, the Foreign Relations Law of the United States, St. Paul, Minnesota: American Law Institute.

------. 2000. Restatement of the Law of Agency, Tentative Draft No.1. St. Paul, Minnesota: American Law Institute.

Ayres, Ian, and Robert Gertner. 1989. "Filling Gaps in Incomplete Contracts: An Economic Theory of Default Rules," 9 Yale Law Journal 87-130.

Barnett, Randy. 1987. "Squaring Undisclosed Agency Law with Contract Theory," 75 California Law Review 1969-2003.

Ben-Shahar, Omri, and Alon Harel. 1995. "Blaming the Victim: Optimal Incentives for Private Precautions Against Crime," 11 Journal of Law, Economics, and Organization 434-455.

Black, Henry. 1990. Black's Law Dictionary. 6th ed. St. Paul, Minnesota: West Publishing Company.

Casadesus-Masanell, Ramon and Daniel F. Spulber. 2002. “Agency Revisited," working paper, Harvard Business School, April 2002.

Chu, Cyrus, and Yingyi Qian. 1995. "Vicarious Liability under a Negligence Rule," 15 International Review of Law and Economics 305-322.

Cohen, George M. 1999. "The Collusion Problem in Agency Law," University of Virginia School of Law Legal Studies Working Paper No. 00-2. Social Science Research Network.

http://papers.ssrn.com/sol3/papers.cfm?cfid=349560\&cftoken=62368792\&abstract_id=1 98909.

Cooter, Robert and Bradley Freedman. 1991. "The Fiduciary Relationship: Its Economic Character and Legal Consequences," 66 New York University Law Review 1045-1075.

Davis, Kevin. 1999. "Licensing Lies: Merger Clauses, the Parol Evidence Rule and PreContractual Misrepresentations," 33 Valparaiso University Law Review 485-534.

DeMott, Deborah. 1998. "A Revised Prospectus for a Third Restatement of Agency," 31 U.C. Davis Law Review 1035-1063.

Epstein, Richard A. 1992. "The Path to The T.J. Hooper: The Theory and History of Custom in the Law of Tort," 21 Journal of Legal Studies 1.

Fischel, Daniel and Alan Sykes. 1996. "Corporate Crime," 25 Journal of Legal Studies 319-350.

Fishman, Steven. 1987. 'Inherent Agency Power -- Should Enterprise Liability Apply to Agents' Unauthorized Contracts?" 19 Rutgers Law Journal 1-57.

Friedman, David. 1996. "Rational Criminals and Intentional Accidents: The Economics of Law and Law Breaking," in Hidden Order: The Economics of Everyday Life. New York:

HarperBusiness.

Holmes, Oliver Wendell, Jr. 1891. “Agency II,” 5 Harvard Law Review 1-23.

Holmstrom, Bengt. 1982. "Moral Hazard in Teams," 13 Bell Journal of Economics 324-340. 
Hylton, Keith N. 1996. “Optimal Law Enforcement and Victim Precaution,” 27 RAND Journal of Economics 197-206.

Klein, William and J. Mark Ramseyer. 1994. Teacher's Manual for Cases and Materials on Business Associations, 2nd ed. Westbury, New York: Foundation Press.

Kornhauser, Lewis. 1982. "An Economic Analysis of the Choice between Enterprise and Personal Liability for Accidents," 70 California Law Review 1345-1392.

Landes, Richard and Richard Posner. 1987. The Economic Structure of Tort Law. Cambridge, Mass.: Harvard University Press.

Landes, William M. and Richard A. Posner. 1996. "The Economics of Legal Disputes Over the Ownership of Works of Art and Other Collectibles," in Victor A. Ginsburgh and Pierre-

Michel Menger, eds., Economics of the Arts: Selected Essays. Amsterdam, NY: Elsevier.

Levmore, Saul. 1987. "Variety and Uniformity in the Treatment of the Good Faith Purchaser," 16 Journal of Legal Studies 43-65.

McKay, Bart. 1994. "Inherent Agency Powers: Does Celtic Life Insurance Co. v. Coats Open the Door to a New Theory of Vicarious Liability in Texas?," 46 Baylor Law Review 449461.

Milgrom, Paul and John Roberts. 1992. Economics, Organization, and Management.

Englewood Cliffs, NJ: Prentice-Hall.

Phillips, Michael J. 1991. "Employer Sexual Harassment Liability under Agency Principles: A Second Look at Meritor Savings Bank, FSB v. Vinson," 44 Vanderbilt Law Review 12291272.

Polinsky, A. Mitchell. 1989. An Introduction to Law and Economics. 2nd ed. Boston: Little, Brown and Company.

Posner, Richard. 1986. The Economic Analysis of Law. 3rd ed. Boston: Little, Brown, and Company.

Rasmusen, Eric. 2001a. "Explaining Incomplete Contracts as the Result of Contract-Reading Costs," 1 Advances in Economic Analysis and Policy. No. 1, Art. 2, http://www.bepress.com/bejeap/advances/vol1/iss1/art2.

-----.. 2001b. Games and Information. 3rd ed. Malden, MA: Blackwell.

- and Ian Ayres. 1993. "Mutual Versus Unilateral Mistake in Contracts," 22 Journal of Legal Studies 309-343.

Ribstein, Larry and Peter Letsou. 2003. Business Associations, 4th Edition (August 1, 2002 draft),

Anderson Publishing: 2003.

Shavell, Steven. 1980. "Strict Liability versus Negligence," 9 Journal of Legal Studies 1-25.

Spier, Kathryn. 1992. "Incomplete Contracts and Signalling," 23 RAND Journal of Economics 432-443.

Spulber, Daniel F. 1999. Market Microstructure. New York: Cambridge University Press.

Steffen, Roscoe. 1977. Agency-Partnership in a Nutshell. St. Paul, Minnesota: West Publishing Co.

Sykes, Alan. 1984. “The Economics of Vicarious Liability," 93 Yale Law Journal 1231-1280.

------. 1988. "The Boundaries of Vicarious Liability: An Economic Analysis of the Scope of

Employment Rule and Related Legal Doctrines," 101 Harvard Law Review 563-609.

Whincop, M.J. 1997. "Nexuses of Contracts, the Authority of Corporate Agents, and Doctrinal Indeterminacy: From Formalism to Law and Economics," 20 University of New South

Wales Law Journal 274-310.

Williston, Samuel. 1957. A Treatise on the Law of Contracts, 3rd Edition. Walter Jaeger, ed. Mt. Kisco, New York: Baker.

\section{Case References}


Belton v. Washington Metro. Area Transit Auth., 20 F.3d 1197 (Williams, J., D.C. Cir., 1994)

Botany Worsted Mills v. U.S., 278 U.S. 282 (1929)

Butler v. Maples, 76 U.S. 766 (1869)

Cange v. Stotler, 826 F.2d 581 (7th Cir. 1987)

Cullen v. BMW, 490 F. Supp. 249 (E.D.N.Y. 1980)

First Fidelity Bank, N.A. v. Antigua and Barbuda, 877 F.2d 189 (2d Cir. 1989)

General Overseas Films, Ltd. v. Robin Int'l, Inc., 542 F. Supp. 684 (S.D.N.Y. 1982), aff'd, 718 F.2d 1085 (2d Cir. 1983)

Hadley v. Baxendale, 9 Ex. 341, 156 Eng. Rptr. 145 (1854)

Hallock v. State, 64 N.Y.2d 224 (1984)

Hope Lutheran Church v. Chellew, 460 N.E.2d 1244 (1st Dist. 1984)

Indiana Code. 1996. Sec. 25-34.1-10-10

Hubbard v. Tenbrook, 124 Pa. 291 (1889)

Jansen v. Packaging Co., Ellerth v. Burlington, 123 F.3d 490 (7th Cir. 1997), en banc

Jones v. Taylor, 401 S.W.2d 183 (1966)

Kelly Asphalt Block Co. v. Barber Asphalt Paving Co., 211 N.Y. 68 (1914)

Li v. Yellow Cab Co., 13 Cal. 3d 804 (1975)

Metropolitan Club vs. Hopper, 153 Md. 666, 139 A. 554 (1927)

Minskoff Equities v. American Express, 94 Civ. 967 (RPP) (S.D.N.Y. 1995)

Mussey v. Beecher, 57 Mass. (3 Cush.) 511 (1849)

Nelson v. Wolf, 4 N.J. 76 (1950)

North Alabama Grocery Co. v. J.C. Lysle Milling Co., 205 Ala. 484 (1921)

Porter v. Wertz, 416 N.Y.S.2d 254 (1979), aff'd, 53 N.Y. 2d 696, (1981)

Rothman v. Fillette, 503 Pa. 259 (1983)

Rykaczewski v. Kerry Home, Inc., 192 Pa. Super. 461 (1960)

Secon Service System v. St. Joseph Bank and Trust, 855 F.2d 406 ( $7^{\text {th }}$ Cir. 1988)

Steinberg v. Mikkelsen, 901 F. Supp. 1433 (E.D. Wisc. 1995)

The T.J. Hooper, 60 F.2d 737 (2d Cir. 1932)

Union Mutual Life Insurance Co. v. Wilkinson, 80 U.S. 222 (1871)

Watteau v. Fenwick, 1 Q.B. 346 (1892)

Woodstock Iron Company v. Richmond and Danville Extension, 129 US 643, 662 (1889)

Zendman v. Harry Winston, 305 N.Y. 180 (1953) 